\title{
Hypereosinophilic syndrome with Loeffler endocarditis
}

\section{Urška Dolores \\ Breskvar Kač , Ljupka Dimitrovska, Jana Ambrožič, Mojca Bervar}

University Medical Centre Ljubljana, Ljubljana, Slovenia

\section{RECEIVED:}

March 11, 2017

ACCEPTED:

April 6, 2017

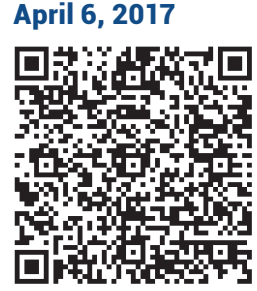

KEYWORDS: cardiomyopathy, hypereosinophilic syndrome, intracardiac thrombus, echocardiography CITATION: Cardiol Croat. 2017;12(4):141. | https://doi.org/10.15836/ccar2017.141

*ADDRESS FOR CORRESPONDENCE: Urška Dolores Breskvar Kač, Univerzitetni klinični center Ljubljana, Zaloška cesta 7, 1000 Ljubljana, Slovenia. / Phone: +386-41-935-584 / E-mail: udbreskvar@yahoo.com

ORCID: Urška Dolores Breskvar Kač, http://orcid.org/0000-0002-3139-1345

Ljupka Dimitrovska, http://orcid.org/0000-0002-2467-5438 • Jana Ambrožič, http://orcid.org/0000-0003-4864-7244 Mojca Bervar, http://orcid.org/0000-0002-1313-8928

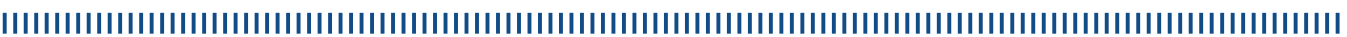

Introduction: Hypereosinophilic syndromes (HES) are a group of multisystemic disorders marked by a sustained overproduction of eosinophils, in which eosinophilic infiltration and mediator release cause damage to multiple organs. ' Cardiac involvement is present in $40 \%$ of cases and is one of the most serious manifestations of HES, accounting for approximately one-half of deaths. ${ }^{2}$ We report a case of Loeffler endocarditis detected by echocardiography

Case report: 68 -year-old male presented with symptoms of behavioural changes. The patient was diagnosed with rheumatic polimyalgia two years ago and treated with low-dose prednisolon. Development of eosinophilic granulomatosis with polyangiitis (EGPA) has been suspected. Magnetic resonance imaging of the brain revealed multiple ischemic lesions. Two-dimensional transthoracic echocardiography (TTE) showed a normally sized left ventricle with normal systolic function without regional wall motion abnormalities and no signs of diastolic disfunction. The valves showed no significant pathology. An echodense structure that obliterated the left ventricular apex was detected, consistent with thrombus (Figure 1). The formation was further investigated with administration of contrast (Sonovue) and three-dimensional TTE and transesophageal echocardiography. Loeffler endocarditis with apical thrombus was suspected with distant embolization to the central nervous system. Highdose prednisolone therapy in combination with pulsed cyclophosphamide regimen was started and anticoagulation therapy with warfarin was instituted. The symptoms began to resolve and the patient reports no further manifestations of the disease. Serial monthly follow-up TTE exams demonstrate apical thrombus regression and no further cardiac involvement so far.

Discussion and Conclusion: Eosinophil-mediated heart damage evolves through three stages. The early stage of cardiac involvement begins with eosinophilic infiltration, followed by an intermediate thrombotic stage, and, finally, a late fibrotic stage, resulting in endomyocardial fibrosis, leading to restrictive cardiomyopathy. ${ }^{2}$ The major complication of intracardiac thrombus formation is the detachment and distal embolization of thrombotic material, leading to embolic events, which are a major cause of morbidity among patients with HES. ${ }^{3,4}$

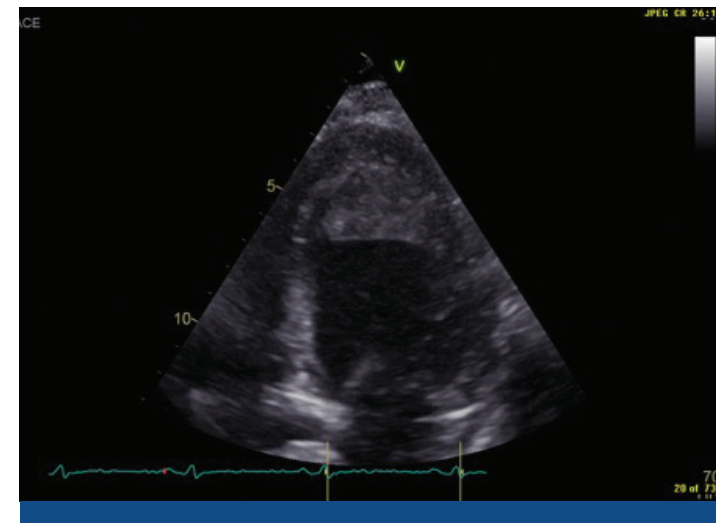

FIGURE 1. Transthoracic echocardiography. Apical four chamber view. A homogenous echodense mass in the left ventricular apex

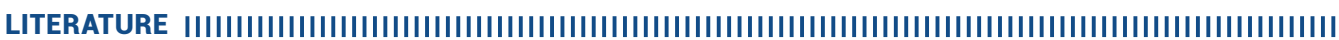

1. Valent P, Klion AD, Horny HP, Roufosse F, Gotlib J, Weller PF, et al. Contemporary consensus proposal on criteria and classification of eosinophilic disorders and related syndromes. J Allergy Clin Immunol. 2012 Sep;130(3):607-612.e9. https://doi.org/10.1016/j.jaci.2012.02.019

2. Ogbogu PU, Rosing DR, Horne MK 3rd. Cardiovascular manifestations of hypereosinophilic syndromes. Immunol Allergy Clin North Am. 2007 Aug;27(3):457-75. https://doi.org/10.1016/j.iac.2007.07.001

3. Chang SA, Kim HK, Park EA, Kim YJ, Sohn DW. Images in cardiovascular medicine. Loeffler endocarditis mimicking apical hypertrophic cardiomyopathy. Circulation. 2009 Jul 7;120(1):82-5. https://doi.org/10.1161/CIRCULATIONAHA.108.833566

4. Wang S, Wang A, Guo B, Zhu S, Chi Z, Zhao X. Löffler endocarditis with multiple cerebral embolism. J Stroke Cerebrovasc Dis. 2014 Jul;23(6):170912. https://doi.org/10.1016/j.jstrokecerebrovasdis.2013.10.023 